\title{
A review of antibiotic prophylaxis for traveler's diarrhea: past to present
}

\author{
Ajib Diptyanusa, Thundon Ngamprasertchai ${ }^{*}$ and Watcharapong Piyaphanee
}

\begin{abstract}
As there is rapid increase in international travel to tropical and subtropical countries, there will likely be more people exposed to diarrheal pathogens in these moderate to high risk areas and subsequent increased concern for traveler's diarrhea. The disease may appear as a mild clinical syndrome, yet a more debilitating presentation can lead to itinerary changes and hospitalization. As bacterial etiologies are the most common causative agents of TD, the use of antibiotic prophylaxis to prevent TD has been reported among travelers for several years. The most common type of antibiotic used for TD has changed over 50 years, depending on many influencing factors. The use of antibiotic prophylaxis for TD prevention in travelers is still controversial, mainly because of difficulties balancing the risks and benefits. Many factors, such as emerging drug resistance, side effects, cost and risk behavior need to be considered. This article aims to review antibiotic prophylaxis from the 1950s to 2000s, to describe the trend and reasons for different antibiotic use in each decade. We conclude that prophylactic antibiotics should be restricted to some high-risk travelers or short-term critical trips.
\end{abstract}

Keywords: Antibiotic, Prophylaxis, Prevention, traveler's diarrhea

\section{Introduction}

International travel is rapidly increasing, with 1.2 billion travelers in 2016, and Asian and Pacific regions being particularly popular [1]. Traveler's diarrhea (TD) is one of the most common travel-related illnesses among short-term travelers to low- and middle-income countries [2, 3]. Incidence of TD ranges from 2 to $57 \%$, for different traveler characteristics and destinations [4-10]. High risk destinations for contracting TD include most countries in Asia, the Middle East, Africa, Mexico, and Central and South America [11, 12]. Most TD usually results in mild symptoms and is self-limiting [13, 14], however clinical symptoms can be severe and cause several issues, including disruption to travel, or long-term effects and hospitalization $[15,16]$.

\section{Etiology of traveler's diarrhea}

The causative pathogens of TD vary in each region, but bacteria are the most common, followed by viruses and protozoa. In Latin America and the Caribbean, the most

\footnotetext{
* Correspondence: thundon.ngm@mahidol.ac.th

Department of Clinical Tropical Medicine, Faculty of Tropical Medicine,

Mahidol University, 420/6 Ratchawithi Road, Ratchathewi, Bangkok 10400,

Thailand
}

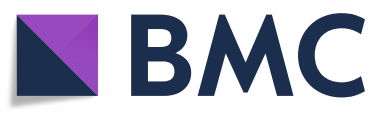

(c) The Author(s). 2018 Open Access This article is distributed under the terms of the Creative Commons Attribution 4.0 International License (http://creativecommons.org/licenses/by/4.0/), which permits unrestricted use, distribution, and

reproduction in any medium, provided you give appropriate credit to the original author(s) and the source, provide a link to the Creative Commons license, and indicate if changes were made. The Creative Commons Public Domain Dedication waiver (http://creativecommons.org/publicdomain/zero/1.0/) applies to the data made available in this article, unless otherwise stated. chia coli (ETEC) and enteroaggregative E. coli (EAEC) [17, 18]. In addition, ETEC has been documented as the most common pathogen in travelers returning from African countries [19]. As well as ETEC, Campylobacter, Giardia and Shigella have frequently been reported to cause TD in travelers in the Indian subcontinent [20,21]. Interestingly, Campylobacter is the most common pathogen isolated from travelers returning from Southeast Asia [17, 22]. Increasing reports of norovirus in travelers returning from multiple regions of the world are of concern, as it is an important cause of TD [23].

Travelers to remote areas far from medical facilities are often advised to take antibiotics when symptoms of TD develop [24]. In contrast, some high-risk groups, such as immunocompromised travelers, might prefer to take antibiotics prophylactically to prevent TD. There have been many reports that bacterial etiology is the most common cause of TD, therefore antibiotic use might be the most effective method of prevention [17-22]. It has been reported previously that approximately $15 \%$ of travelers take antibiotics to prevent TD [25]. However, the use of antibiotic prophylaxis for TD prevention in travelers is still 
controversial, mainly because of the challenge of managing risks and benefits [26].

\section{Antibiotic prophylaxis}

Traditionally, standard pre-travel consultations include advice to "boil it, cook it, peel it, or forget it" to prevent TD [11]; nevertheless, studies have reported that even travelers who follow these rules may develop TD [27, 28]. Therefore, the use of antibiotic prophylaxis for travelers could be considered, to decrease the pathogen burden and prevent long-term morbidity $[29,30]$. The prophylactic antibiotic of choice has been changing over the last few decades, as resistance patterns developed [31]. According to previously published randomized controlled trials (RCTs), antibiotic efficacy varies from $28 \%$ up to $72 \%$ [32-36], for different types of antibiotics and traveler's destinations.

\section{Method}

We searched the PubMed database for publications on the protective efficacy of antibiotics as chemoprophylaxis for TD. Search terms included antibiotics, travel, diarrhea, neomycin, furazolidone, doxycycline, trimethoprim/sulfamethoxazole, erythromycin, mecillinam, bicozamycin, ciprofloxacin, norfloxacin, azithromycin and rifaximin. All search articles yielded 616 in numbers. Inclusion criteria were papers written in English and related to the use of antibiotics as prophylaxis for TD. Overall, 27 studies were included in this review, to illustrate the trend of antibiotic use in the prevention of TD over the past 50 years (as shown in Table 1).

\section{Results}

\section{Enterovioform, neomycin, phthalylsulfathiazole and} furazolidone

The first attempt to use antibiotics to prevent TD was in the late 1950s, using enterovioform and neomycin [37]. Since the use of enterovioform-an iodochlorhydroxyquin-was associated with myelo-optic neuropathy, the drug was withdrawn from the market [38]. In the early 1960s, a double-blind study was conducted in American college students in Mexico City, to compare a placebo with low doses of neomycin sulfate and a sulfonamide called phthalylsulfathiazole [39]. Low protective efficacy was observed in neomycin sulfate, yet phthalylsulfathiazole halved the incidence of TD. There were no adverse drug reactions reported during the 14-day study. Another trial using neomycin-trisulfamide, Streptotriad (a combination of streptomycin and triple sulphonamides), or a placebo was conducted in British Airways personnel and their families, traveling to different countries worldwide, for up to 3 weeks [40]. Both drugs resulted in a low protection rate against TD. Comparable low protective efficacy was reported in the use of a nitrofuran derivative furazolidone for TD prophylaxis in 223 Royal Air Force pilots [41].

\section{Doxycycline}

During the late 1970s, doxycycline was used initially. The role of doxycycline for the prevention of TD was supported by research that showed the drug was highly effective against ETEC as major cause of TD, had long-acting properties and minimal adverse events [42]. Daily administration of $100 \mathrm{mg}$ of doxycycline for 3 weeks was up to $86 \%$ effective for TD prevention among American Peace Corps Volunteers, deployed to multiple regions of the world [43, 44]. Unfortunately, lower protective efficacy was observed over the proceeding 5 years, because of high proportions of tetracycline-resistant ETEC [45-47]. Hence, a trial using a higher dose of doxycycline (200 mg per day) was conducted. The results showed a significant reduction in the incidence of TD, but $12 \%$ of cases reported gastric upset in the doxycycline group [48]. Today, because of the high risk of antimicrobial resistance and potential side effects from using doxycycline, no guidelines recommended its use.

\section{Trimethoprim/sulfamethoxazole}

During the late 1970 s to early 1980s, some studies showed that the use of trimethoprim/sulfamethoxazole (TMP/SMX) prophylaxis resulted in a significantly higher reduction of TD incidence in college students traveling to Guadalajara, Mexico when compared with a placebo and TMP alone [49, 50]. Administration of $160 \mathrm{mg}$ TMP and $800 \mathrm{mg}$ SMX twice daily for 3 weeks yielded a protective efficacy of $71 \%$ [49]. Another study showed that the same daily dosage of TMP/SMX for 14 days resulted in 95\% protection against TD [50]. Emerging drug resistance was a concern, as a higher resistance pattern for $E$. coli had been observed since the early 1980s [50-52]. Dermatologic adverse reactions, especially skin rashes, were also reported.

\section{Erythromycin, mecillinam and bicozamycin}

Emerging drug resistance resulted in the need to find new regimens for the chemoprophylaxis of TD (Fig. 1). In early 1980s, trials in TD prevention using erythromycin, mecillinam and bicozamycin were conducted. This is because erythromycin had been reported to eliminate Enterobacteriaceae from human fecal flora without evidence of recolonization [53]. A placebo-controlled RCT on American travelers to Mexico, using $1 \mathrm{~g}$ erythromycin during travel showed a protective efficacy of $71 \%$ against TD [54]. Furthermore, a non-absorbable antibiotic, mecillinam, was also identified as having selective bactericidal activity against Enterobacteriaceae [55]. A trial using $200 \mathrm{mg}$ of mecillinam for 25 days as prophylaxis for TD was conducted in adult travelers visiting Asia, Africa or Latin America, resulting in $75 \%$ protection against 
Table 1 Selected publications showing prophylactic antibiotic use and its protection rate against TD in chronological order from oldest to newest

\begin{tabular}{|c|c|c|c|c|}
\hline Publication year & Drug name & Participants studied & Protection rate (\%) & Reference \\
\hline \multicolumn{5}{|l|}{ 1960s } \\
\hline 1962 & Neomycin & 305 & 32 & [39] \\
\hline 1962 & Phthalylsulfathiazole & 336 & 50 & [39] \\
\hline \multicolumn{5}{|l|}{ 1970s } \\
\hline 1978 & Doxycycline & 39 & 86 & [43] \\
\hline 1979 & Doxycycline & 50 & 83 & [44] \\
\hline \multicolumn{5}{|l|}{ 1980s } \\
\hline 1981 & Doxycycline & 46 & 27 & {$[45]$} \\
\hline 1981 & Erythromycin & 48 & 71 & [54] \\
\hline 1982 & TMP/SMX & 147 & 71 & [49] \\
\hline 1983 & TMP/SMX & 87 & 95 & {$[50]$} \\
\hline 1983 & Mecillinam & 74 & 75 & {$[56]$} \\
\hline 1983 & Doxycycline & 145 & 81 & {$[48]$} \\
\hline 1984 & Doxycycline & 63 & 68 & {$[46]$} \\
\hline 1984 & Doxycycline & 44 & 59 & [47] \\
\hline 1985 & Mecillinam & 32 & 66 & [57] \\
\hline 1985 & Bicozamycin & 30 & 100 & [59] \\
\hline 1986 & Norfloxacin & 115 & 88 & [63] \\
\hline 1987 & Norfloxacin & 115 & 70 & [64] \\
\hline 1989 & Ciprofloxacin & 59 & 94 & {$[61]$} \\
\hline \multicolumn{5}{|l|}{ 1990s } \\
\hline 1990 & Norfloxacin & 222 & 93 & {$[65]$} \\
\hline 1994 & Ciprofloxacin & 21 & 100 & {$[62]$} \\
\hline 1994 & Ciprofloxacin & 99 & 84 & [51] \\
\hline 1994 & TMP/SMX & 87 & 51 & [51] \\
\hline 1996 & Azithromycin & 231 & 81 & {$[72]$} \\
\hline \multicolumn{5}{|l|}{$2000 \mathrm{~s}$} \\
\hline 2005 & Rifaximin & 210 & 72 & [33] \\
\hline 2010 & Rifaximin & 95 & 67 & [34] \\
\hline 2010 & Rifaximin & 201 & 58 & [35] \\
\hline 2011 & Rifaximin & 98 & 28 & {$[32]$} \\
\hline 2013 & Rifaximin & 239 & 48 & {$[36]$} \\
\hline
\end{tabular}

TD [56]. A similar protection rate was reported among Danish travelers to Mexico [57]. However, it should be noted that etiology of most TD cases remained unknown. Bicozamycin, or bicyclomycin, has been found to have similar activity against Enterobacteriaceae [58]. Administration of $500 \mathrm{mg}$ of bicozamycin four times daily for 21 days, to adult US citizens traveling to Guadalajara, Mexico, showed high protection against TD [59]. As well as the inconvenience of frequent pill taking for travelers, resistance of bicozamycin had also been detected [59]. The drug was not further developed for human use.

\section{Fluoroquinolones: ciprofloxacin and norfloxacin}

Discovery of quinolone antibiotics gave researchers hope to prevent traveler's diarrhea, as this group of antibiotics is highly effective against gram-negative pathogens including Enterobacteriaceae [60]. The early clinical trials using ciprofloxacin and norfloxacin were conducted during the late 1980s and early 1990s [51, 61-65]. These two drugs have been shown to be highly effective in the prevention of TD, with less frequent adverse events. Administration of $500 \mathrm{mg}$ of ciprofloxacin daily in two studies demonstrated protective efficacies of $84 \%$ and $94 \%[51,61]$. To compare fluoroquinolones with 


\begin{tabular}{|c|c|c|c|c|}
\hline \multirow[b]{2}{*}{1960} & \multicolumn{2}{|c|}{$\begin{array}{l}\text { Doxycycline: } \\
\text { Decreasing protective effi- } \\
\text { cacy over the years due to } \\
\text { tetracycline-resistant ETEC. }\end{array}$} & \multicolumn{2}{|c|}{$\begin{array}{l}\text { Azithromycin: } \\
\text { Minimally reported. } \\
\text { Fluoroquinolones: } \\
\text { Highly efficaceous, yet drug } \\
\text { resistance has been emerging } \\
\text { particularly in Southeast Asia. }\end{array}$} \\
\hline & 1970 & 1980 & 1990 & 2000 \\
\hline \multicolumn{2}{|c|}{$\begin{array}{l}\text { Enterovioform: } \\
\text { Associated with myelo- } \\
\text { optic neuropathy. } \\
\text { Neomycin, Furazolidone: } \\
\text { Low protection agaist TD. }\end{array}$} & \multicolumn{2}{|c|}{$\begin{array}{l}\text { TMP/SMX: } \\
\text { Issues regarding drug resis- } \\
\text { tance and dermatologic ad- } \\
\text { verse events. } \\
\text { Erythromycin, Mecillinam, } \\
\text { Bicozamycin: } \\
\text { Insufficient trials and possible } \\
\text { drug resistance issue. }\end{array}$} & $\begin{array}{l}\text { Rifaximin: } \\
\text { Various levels of protec- } \\
\text { tion against TD and drug } \\
\text { resistance has not yet } \\
\text { been frequently reported. }\end{array}$ \\
\hline
\end{tabular}

Fig. 1 Timeline of prophylactic antibiotic use against TD in chronological order

previous antibiotics, ciprofloxacin provided a higher protection rate, compared with TMP/SMX (84\% versus $51 \%$, respectively); however, the Asian region was not included in this study. A double-blind randomized trial using $250 \mathrm{mg}$ of ciprofloxacin was conducted in a Himalayan expedition team in 1994, yet the protection rate for TD was not clearly reported [62]. Further studies using norfloxacin with a dose of either $400 \mathrm{mg}$ daily or $200 \mathrm{mg}$ twice daily showed $70-93 \%$ protection against TD [63-65].

Antibiotic resistance to fluoroquinolones, especially in Campylobacter species has been reported, particularly in Southeast Asia [66-68]. Broad use of fluoroquinolones in both humans and in animals along with chromosomal mutations in drug's target enzymes and efflux systems, were sufficient to cause important levels of clinical resistance $[69,70]$. In addition to its ease in drug resistance development, the risk of tendinitis/tendinopathy, QT prolongation, and delirium could limit the use of fluoroquinolones for TD prevention [2, 71].

\section{Azithromycin}

The protective effect of azithromycin against dysenteric diarrhea has been accidentally discovered during malaria chemoprophylaxis efficacy trial in Kenya in 1995. A total of 231 volunteers were divided into 4 arms: azithromycin $250 \mathrm{mg}$ daily, azithromycin $1000 \mathrm{mg}$ weekly, doxycycline $100 \mathrm{mg}$ daily, or placebo. Result showed that only $2.6 \%$ of volunteers in the daily or weekly azithromycin groups developed dysentery, while $13.9 \%$ of volunteer in doxycycline or placebo group developed dysentery in the same period, so the estimated protective efficacy of azithromycin was $81 \%$ [72]. Unfortunately, although azithromycin is very well known for its efficacy in treatment of TD; the study of its use as chemoprophylaxis against TD is rarely reported.

\section{Rifaximin}

Side effects and development of resistance among extraintestinal bacteria means the use of absorbable (systemic) antibiotics to prevent TD has been discouraged [73]. In the 1990s, an antibiotic called rifaximin was discovered and shown to be effective for the prevention of TD without causing significant adverse effects. Rifaximin is a rifamycin derivative, which is poorly absorbed and able to reach high concentrations in the intestinal lumen [74]. Rifaximin has also been shown to effectively prevent shigellosis [75].

Studies in short-term travelers to Mexico, using various regimens of rifaximin for 14 days, demonstrated protective efficacies ranging from 28 to $72 \%$ [32, 33, 35]. Another study showed that the use of a higher dose of $1100 \mathrm{mg}$ rifaximin for 14 days resulted in $67 \%$ protection against TD in military personnel deployed to Turkey [34]. The latest trial using $200 \mathrm{mg}$ of rifaximin, twice daily from the day of departure to 7 days post-return in adult travelers visiting South Asia and Southeast Asia, showed a protective efficacy of $48 \%$ [36].

Low to moderate efficacy of rifaximin has been observed in several studies, however the majority of the studies [33-36] did not report the resistance pattern of the causative pathogen. Therefore, it remains unclear 
whether the low protection level was because of rifaximin resistance. One study reported unusually high rifaximin resistant $E$. coli in several countries [76].

\section{Factors to consider and recommendations}

Several factors need consideration when prescribing prophylactic antibiotics for the prevention of TD. Individual risk assessment, including type of population (Table 2), travel purpose and itinerary will be helpful for making prescribing decisions [31]. All the RCTs reported here were conducted in travelers from high-income countries. Applying similar regimens to travelers from low- or middle-income countries may not yield similar efficacy. Furthermore, the incidence of TD in Asian travelers only ranges from 1.6 to $8 \%$, therefore in general travelers, reducing the incidence of TD with antibiotic prophylaxis may not be beneficial [7-9]. Immunocompromised travelers, those taking important trips, or visiting remote locations with a lack of medical provision, may be targeted for antibiotic prophylaxis [26, 31]. As up to $50 \%$ of immunocompromised travelers will experience a gastrointestinal illness including diarrhea [77], it is advisable for this group of travelers to take prophylactic antibiotics; otherwise they will be at risk of more severe illness and hospitalization during travel [78]. In addition, drug side effects should also be considered when making prescribing decisions [79].

Host microbiome may be an important factor involved in protecting travelers from TD. Alterations in native gut microbiome, known as dysbiosis, are known to be associated with travel [80]. Ingestion of antibiotics could affect gut microbiome by several mechanisms such as decrease the diversity, expansion of the resistant strain, loss of the keystone species that support normal ecology [81]. All of these factors can increase the susceptibility of TD. Unfortunately, even short term antibiotics exposure could disrupt the gut microbiome for a year or more and repeated exposure could delay its recovery [81]. Apart from the use of antibiotic, several factors

Table 2 Types of population that might benefit for TD chemoprophylaxis

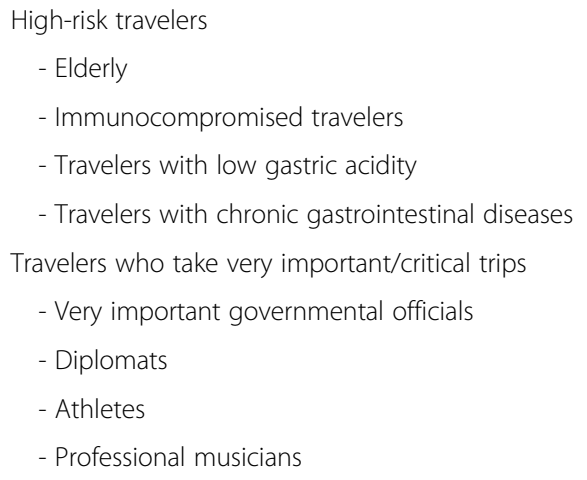

including change of sleeping pattern, exposure to local diet and water or ingestion of antibiotics during the trip can disrupt the gut microbiome $[80,82]$.

Other factors may affect the efficacy of prophylactic antibiotics, such as the predominant pathogens present in each geographical region and their pattern of antibiotic resistance [83]. Drug resistance has emerged over several years, from ETEC resistance to tetracyclines and TMP/SMX, followed by fluoroquinolone-resistant Campylobacter strains from Southeast Asia. Hence, fluoroquinolones should not be prescribed as prophylactic antibiotic for TD in travelers traveling to Southeast Asia. Unfortunately, data for antibiotic resistance are unavailable in some regions of the world, especially in low- and middle-income countries [84]. The current data for rifaximin suggest it could be a suitable prophylactic treatment for TD, as there is no evidence of resistance developing.

Although TD is perceived as a self-limiting disease, it represents a substantial socioeconomic burden from traveler's perspective [85]. This illness may affect not only a change in lifestyle induced by the illness itself, but also expenses for medication and medical services. Cost-benefit analysis, by comparing the cost of antibiotic prophylaxis and treatment involving loss of productivity, may also be a useful approach $[79,86]$.

Current recommendations suggest that antibiotic prophylaxis for TD may be prescribed selectively in some travelers, especially in high-risk short-term travelers [26]. Rifaximin is preferred to other antibiotics because of its poor absorption, reducing the risk of development of resistance in extraintestinal bacteria [26]. However, it is important to note that not all TD is caused by bacteria, so even if we had ideal antibiotics, these would not prevent TD caused by viruses or protozoa.

\section{Conclusions}

Trends in antibiotic use for TD prevention have been changing over several decades. Prophylactic antibiotic prescribing for TD should always include an individual risk assessment, including type of traveler, their destination, travel purpose, itineraries, drug side effects, and cost-benefit analysis. The global increase in antibiotic resistance limits the choice of antibiotics. In the past, doxycycline, TMP/SMX or fluoroquinolones may have been effective for TD prevention; however currently, minimally-absorbed rifaximin is recommended for travelers.

\section{Abbreviations}

EAEC: Enteroaggregative Escherichia coli; ETEC: Enterotoxigenic Escherichia coli; RCT: Randomized controlled trial; TD: Traveler's diarrhea; TMP/ SMX: Trimethoprim/sulfamethoxazole 


\section{Acknowledgements}

We thank Charlotte Robin, from Edanz Group (www.edanzediting.com/ac) for editing a draft of this manuscript.

\section{Funding}

This review did not receive any specific funding.

\section{Availability of data and materials}

Data sharing not applicable to this article as no datasets were generated or analyzed during the current study.

\section{Authors' contributions}

$A D, T N$ and WP performed article extraction and manuscript writing. All authors read and approved the final manuscript.

\section{Ethics approval and consent to participate}

Not applicable.

\section{Consent for publication}

Not applicable.

\section{Competing interests}

The authors declare that they have no competing interests.

\section{Publisher's Note}

Springer Nature remains neutral with regard to jurisdictional claims in published maps and institutional affiliations.

\section{Received: 12 June 2018 Accepted: 22 October 2018}

Published online: 07 November 2018

\section{References}

1. UNWTO Tourism Highlights 2017. 2017. Available from:https://www.eunwto.org/doi/pdf/10.18111/9789284419029. Cited 28 Mar 2018.

2. Giddings SL, Stevens AM, Leung DT. Traveler's diarrhea. Med Clin North Am. 2016:100(2):317-30.

3. Kean BH. The diarrhea of travelers to Mexico. Summary of five-year study. Ann Intern Med. 1963:59:605-14.

4. Pitzurra R, Steffen R, Tschopp A, Mutsch M. Diarrhoea in a large prospective cohort of European travellers to resource-limited destinations. BMC Infect Dis. 2010;10:231

5. Piyaphanee W, Kusolsuk T, Kittitrakul C, Suttithum W, Ponam T, Wilairatana $P$. Incidence and impact of travelers' diarrhea among foreign backpackers in Southeast Asia: a result from Khao san road, Bangkok. J Travel Med. 2011; 18(2):109-14.

6. Echeverria P, Blacklow NR, Sanford LB, Cukor GG. Travelers' diarrhea among American peace corps volunteers in rural Thailand. J Infect Dis. 1981;143(6): 767-71.

7. Kittitrakul C, Lawpoolsri S, Kusolsuk T, Olanwijitwong J, Tangkanakul W, Piyaphanee W. Traveler's diarrhea in foreign travelers in Southeast Asia: a cross-sectional survey study in Bangkok, Thailand. Am J Trop Med Hyg. 2015;93(3):485-90.

8. Mitsui Y, Chanyasanha C, Boonshuyar C, Shimada M, Moji K. Incidence of travelers' diarrhea among Japanese visiting Thailand. Trop Med Health. 2004;32(1):21-6.

9. Chongsuvivatwong V, Chariyalertsak S, McNeil E, Aiyarak S, Hutamai S, Dupont HL, et al. Epidemiology of travelers' diarrhea in Thailand. J Travel Med. 2009:16(3):179-85.

10. Dandoy S. The diarrhea of travelers: incidence in foreign students in the United States. Calif Med. 1966;104(6):458-62.

11. Connor BA. Travelers' diarrhea 2017. Available from: https://wwwnc.cdc.gov/ travel/yellowbook/2018/the-pre-travel-consultation/travelers-diarrhea. Updated June 13, 2017; Cited 28 Mar 2018.

12. Cheng AC, Thielman NM. Update on Traveler's diarrhea. Curr Infect Dis Rep. 2002:4(1):70-7.

13. Steffen R. Epidemiology of traveler's diarrhea. Clin Infect Dis. 2005;41(Suppl 8):S536-40.

14. Hill DR. Occurrence and self-treatment of diarrhea in a large cohort of Americans traveling to developing countries. Am J Trop Med Hyg. 2000; 62(5):585-9.
15. Steffen R, Hill DR, DuPont HL. Traveler's diarrhea: a clinical review. JAMA 2015;313(1):71-80

16. Porter CK, Gloor K, Cash BD, Riddle MS. Risk of functional gastrointestinal disorders in U.S. military following self-reported diarrhea and vomiting during deployment. Dig Dis Sci. 2011;56(11):3262-9.

17. Shah N, DuPont HL, Ramsey DJ. Global etiology of travelers' diarrhea: systematic review from 1973 to the present. Am J Trop Med Hyg. 2009; 80(4):609-14

18. Mason CJ, Sornsakrin S, Seidman JC, Srijan A, Serichantalergs O, Thongsen $\mathrm{N}$, et al. Antibiotic resistance in campylobacter and other diarrheal pathogens isolated from US military personnel deployed to Thailand in 2002-2004: a case-control study. Trop Dis Travel Med Vaccines. 2017;3:13.

19. Jiang ZD, Lowe B, Verenkar MP, Ashley D, Steffen R, Tornieporth N, et al. Prevalence of enteric pathogens among international travelers with diarrhea acquired in Kenya (Mombasa), India (Goa), or Jamaica (Montego Bay). J Infect Dis. 2002;185(4):497-502.

20. Pandey P, Bodhidatta L, Lewis M, Murphy H, Shlim DR, Cave W, et al. Travelers' diarrhea in Nepal: an update on the pathogens and antibiotic resistance. J Travel Med. 2011;18(2):102-8.

21. Swaminathan A, Torresi J, Schlagenhauf $P$, Thursky K, Wilder-Smith A, Connor BA, et al. A global study of pathogens and host risk factors associated with infectious gastrointestinal disease in returned international travellers. J Inf Secur. 2009;59(1):19-27.

22. Laaveri T, Vilkman K, Pakkanen SH, Kirveskari J, Kantele A. A prospective study of travellers' diarrhoea: analysis of pathogen findings by destination in various (sub)tropical regions. Clin Microbiol Infect. 2018;24(8):908.e9-.e16.

23. Koo HL, Ajami NJ, Jiang ZD, Neill FH, Atmar RL, Ericsson CD, et al. Noroviruses as a cause of diarrhea in travelers to Guatemala, India, and Mexico. J Clin Microbiol. 2010:48(5):1673-6.

24. Taylor DN, Hamer DH, Shlim DR. Medications for the prevention and treatment of travellers' diarrhea. J Travel Med. 2017;24(suppl_1):S17-22.

25. Kantele A, Laaveri T, Mero S, Vilkman K, Pakkanen SH, Ollgren J, et al. Antimicrobials increase travelers' risk of colonization by extendedspectrum betalactamase-producing Enterobacteriaceae. Clin Infect Dis. 2015:60(6):837-46.

26. Riddle MS, Connor BA, Beeching NJ, DuPont HL, Hamer DH, Kozarsky P, et al. Guidelines for the prevention and treatment of travelers' diarrhea: a graded expert panel report. J Travel Med. 2017;24(suppl_1):S57-74.

27. Kozicki M, Steffen R, Schar M. Boil it, cook it, peel it or forget it': does this rule prevent travellers' diarrhoea? Int J Epidemiol. 1985;14(1):169-72.

28. Schindler VM, Jaeger VK, Held L, Hatz C, Buhler S. Travel style is a major risk factor for diarrhoea in India: a prospective cohort study. Clin Microbiol Infect. 2015:21(7):676.e1-4.

29. Neal KR, Hebden J, Spiller R. Prevalence of gastrointestinal symptoms six months after bacterial gastroenteritis and risk factors for development of the irritable bowel syndrome: postal survey of patients. BMJ. 1997; 314(7083):779-82

30. Thabane M, Simunovic M, Akhtar-Danesh N, Marshall JK. Development and validation of a risk score for post-infectious irritable bowel syndrome. Am J Gastroenterol. 2009:104(9):2267-74.

31. Connor BA. Travelers' Diarrhea. In: Brunette GW, editor. CDC yellow book 2018: health information for international travel. New York: Oxford University Press; 2017. p. 48-54.

32. Flores J, Dupont HL, Jiang ZD, Okhuysen PC, Melendez-Romero JH, Gonzalez-Estrada A, et al. A randomized, double-blind, pilot study of rifaximin $550 \mathrm{mg}$ versus placebo in the prevention of travelers' diarrhea in Mexico during the dry season. J Travel Med. 2011;18(5):333-6.

33. DuPont HL, Jiang ZD, Okhuysen PC, Ericsson CD, de la Cabada FJ, Ke S, et al. A randomized, double-blind, placebo-controlled trial of rifaximin to prevent travelers' diarrhea. Ann Intern Med. 2005;142(10):805-12.

34. Armstrong AW, Ulukan S, Weiner M, Mostafa M, Shaheen H, Nakhla I, et al. A randomized, double-blind, placebo-controlled study evaluating the efficacy and safety of rifaximin for the prevention of travelers' diarrhea in US military personnel deployed to Incirlik Air Base, Incirlik, Turkey. J Travel Med. 2010; 17(6):392-4.

35. Martinez-Sandoval F, Ericsson CD, Jiang ZD, Okhuysen PC, Romero JH, Hernandez $\mathrm{N}$, et al. Prevention of travelers' diarrhea with rifaximin in US travelers to Mexico. J Travel Med. 2010;17(2):111-7.

36. Zanger P, Nurjadi D, Gabor J, Gaile M, Kremsner PG. Effectiveness of rifaximin in prevention of diarrhoea in individuals travelling to south and 
Southeast Asia: a randomised, double-blind, placebo-controlled, phase 3 trial. Lancet Infect Dis. 2013;13(11):946-54.

37. Kean BH, Waters SR. The diarrhea of travelers. III. Drug prophylaxis in Mexico. N Engl J Med. 1959;261(2):71-4

38. Nakae K, Yamamoto S, Shigematsu I, Kono R. Relation between subacute myelo-optic neuropathy (S.M.O.N.) and clioquinol: nationwide survey. Lancet. 1973;1 (7796):171-3.

39. Kean BH, Schaffner W, Brennan RW. The diarrhea of travelers. V. Prophylaxis with phthalylsulfathiazole and neomycin sulphate. JAMA. 1962;180:367-71.

40. Turner AC. Traveller's diarrhoea: a survey of symptoms, occurrence, and possible prophylaxis. Br Med J. 1967;4(5580):653-4.

41. Nelson SR, Jones HL, Ross JB. Trial of furazolidone as a prophylactic in traveller's diarrhoea. Practitioner. 1962;188:654-5.

42. Sack RB. Prophylactic antimicrobials for traveler's diarrhea: an early history. Clin Infect Dis. 2005;41(Suppl 8):S553-6.

43. Sack DA, Kaminsky DC, Sack RB, Itotia JN, Arthur RR, Kapikian AZ, et al. Prophylactic doxycycline for travelers' diarrhea. Results of a prospective double-blind study of peace corps volunteers in Kenya. N Engl J Med. 1978; 298(14):758-63.

44. Sack RB, Froehlich JL, Zulich AW, Hidi DS, Kapikian AZ, Orskov F, et al. Prophylactic doxycycline for travelers' diarrhea: results of a prospective double-blind study of peace corps volunteers in Morocco. Gastroenterology. 1979;76(6):1368-73.

45. Santosham M, Sack RB, Froehlich J, Greenberg H, Yolken R, Kapikain A, et al. Biweekly prophylactic doxycycline for travelers' diarrhea. J Infect Dis. 1981; 143(4):598-602.

46. Sack RB, Santosham M, Froehlich JL, Medina C, Orskov F, Orskov I. Doxycycline prophylaxis of travelers' diarrhea in Honduras, an area where resistance to doxycycline is common among enterotoxigenic Escherichia coli. Am J Trop Med Hyg. 1984;33(3):460-6.

47. Echeverria P, Sack RB, Blacklow NR, Bodhidatta P, Rowe B, McFarland A. Prophylactic doxycycline for travelers' diarrhea in Thailand. Further supportive evidence of Aeromonas hydrophila as an enteric pathogen. Am J Epidemiol. 1984;120(6):912-21.

48. Freeman LD, Hooper DR, Lathen DF, Nelson DP, Harrison WO, Anderson DS Brief prophylaxis with doxycycline for the prevention of traveler's diarrhea. Gastroenterology. 1983;84(2):276-80.

49. DuPont HL, Evans DG, Rios N, Cabada FJ, Evans DJ Jr, DuPont MW. Prevention of travelers' diarrhea with trimethoprim-sulfamethoxazole. Rev Infect Dis. 1982:4(2):533-9.

50. Dupont HL, Ericsson CD, Galindo E, Dupont MW, Mendiola Gomez J. Antimicrobial therapy of travellers' diarrhoea. Scand J Gastroenterol Suppl. 1983:84:99-105.

51. Heck JE, Staneck JL, Cohen MB, Weckbach LS, Giannella RA, Hawkins J, et al. Prevention of Travelers' diarrhea: ciprofloxacin versus trimethoprim/ sulfamethoxazole in adult volunteers working in Latin America and the Caribbean. J Travel Med. 1994;1(3):136-42.

52. Murray BE, Mathewson JJ, DuPont HL, Ericsson CD, Reves RR. Emergence of resistant fecal Escherichia coli in travelers not taking prophylactic antimicrobial agents. Antimicrob Agents Chemother. 1990;34(4):515-8.

53. Andremont A, Sancho-Garnier H, Tancrede C. Epidemiology of intestinal colonization by members of the family Enterobacteriaceae highly resistant to erythromycin in a hematology-oncology unit. Antimicrob Agents Chemother. 1986;29(6):1104-7.

54. Andremont A, Tancrede C. Reduction of the aerobic gram negative bacterial flora of the gastro-intestinal tract and prevention of traveller's diarrhea using oral erythromycin. Ann Microbiol (Paris). 1981;132 B(3):419-27.

55. Tybring L. Mecillinam (FL 1060), a 6beta-amidinopenicillanic acid derivative: in vitro evaluation. Antimicrob Agents Chemother. 1975;8(3):266-70.

56. Black FT, Gaarslev K, Orskov F, Orskov I, Stenderup A, Stenderup J, et al. Mecillinam, a new prophylactic for travellers' diarrhoea. A prospective double-blind study in tourists travelling to Egypt and the Far East. Scand J Infect Dis. 1983;15(2):189-93.

57. Gaarslev K, Stenderup J. Changes during travel in the composition and antibiotic resistance pattern of the intestinal Enterobacteriaceae flora: results from a study of mecillinam prophylaxis against travellers' diarrhoea. Curr Med Res Opin. 1985;9(6):384-7.

58. Nishida M, Mine Y, Matsubara T, Goto S, Kuwahara S. Bicyclomycin, a new antibiotic. 3. In vitro and in vivo antimicrobial activity. J Antibiot (Tokyo). 1972;25(10):582-93.
59. Ericsson CD, DuPont HL, Galindo E, Mathewson JJ, Morgan DR, Wood LV, et al. Efficacy of bicozamycin in preventing traveler's diarrhea. Gastroenterology. 1985;88(2):473-7.

60. Aldred KJ, Kerns RJ, Osheroff N. Mechanism of quinolone action and resistance. Biochemistry. 2014;53(10):1565-74.

61. Rademaker CM, Hoepelman IM, Wolfhagen MJ, Beumer H, RozenbergArska M, Verhoef J. Results of a double-blind placebo-controlled study using ciprofloxacin for prevention of travelers' diarrhea. Eur J Clin Microbiol Infect Dis. 1989;8(8):690-4.

62. Parry H, Howard AJ, Galpin OP, Hassan SP. The prophylaxis of travellers' diarrhoea; a double blind placebo controlled trial of ciprofloxacin during a Himalayan expedition. J Inf Secur. 1994;28(3):337-8.

63. Johnson PC, Ericsson CD, Morgan DR, Dupont HL, Cabada FJ. Lack of emergence of resistant fecal flora during successful prophylaxis of traveler's diarrhea with norfloxacin. Antimicrob Agents Chemother. 1986;30(5):671-4.

64. Wistrom J, Norrby SR, Burman LG, Lundholm R, Jellheden B, Englund G. Norfloxacin versus placebo for prophylaxis against travellers' diarrhoea. J Antimicrob Chemother. 1987;20(4):563-74.

65. Scott DA, Haberberger RL, Thornton SA, Hyams KC. Norfloxacin for the prophylaxis of travelers' diarrhea in U.S. military personnel. Am J Trop Med Hyg. 1990;42(2):160-4.

66. Vlieghe ER, Jacobs JA, Van Esbroeck M, Koole O, Van Gompel A. Trends of norfloxacin and erythromycin resistance of campylobacter jejuni/ campylobacter coli isolates recovered from international travelers, 1994 to 2006. J Travel Med. 2008;15(6):419-25.

67. Luangtongkum T, Jeon B, Han J, Plummer P, Logue CM, Zhang Q. Antibiotic resistance in campylobacter: emergence, transmission and persistence. Future Microbiol. 2009;4(2):189-200.

68. Hoge CW, Gambel JM, Srijan A, Pitarangsi C, Echeverria P. Trends in antibiotic resistance among diarrheal pathogens isolated in Thailand over 15 years. Clin Infect Dis. 1998;26(2):341-5.

69. Endtz HP, Ruijs GJ, van Klingeren B, Jansen WH, van der Reyden T, Mouton RP. Quinolone resistance in campylobacter isolated from man and poultry following the introduction of fluoroquinolones in veterinary medicine. J Antimicrob Chemother. 1991;27(2):199-208.

70. Hooper DC. Emerging mechanisms of fluoroquinolone resistance. Emerg Infect Dis. 2001;7(2):337-41.

71. Owens RC Jr, Ambrose PG. Antimicrobial safety: focus on fluoroquinolones. Clin Infect Dis. 2005;41(Suppl 2):S144-57.

72. Shanks GD, Ragama OB, Aleman GM, Andersen SL, Gordon DM. Azithromycin prophylaxis prevents epidemic dysentery. Trans R Soc Trop Med Hyg. 1996;90(3):316.

73. Gorbach S, Edelman R. Travelers' diarrhea: National Institutes of Health consensus development conference. Bethesda, Maryland, January 28-30, 1985. Rev Infect Dis. 1986;8(Suppl 2):S109-233.

74. Jiang ZD, Ke S, Palazzini E, Riopel L, Dupont H. In vitro activity and fecal concentration of rifaximin after oral administration. Antimicrob Agents Chemother. 2000;44(8):2205-6.

75. Taylor DN, McKenzie R, Durbin A, Carpenter C, Atzinger CB, Haake R, et al. Rifaximin, a nonabsorbed oral antibiotic, prevents shigellosis after experimental challenge. Clin Infect Dis. 2006:42(9):1283-8.

76. Gomes C, Ruiz L, Pons MJ, Ochoa TJ, Ruiz J. Relevant role of efflux pumps in high levels of rifaximin resistance in Escherichia coli clinical isolates. Trans $\mathrm{R}$ Soc Trop Med Hyg. 2013;107(9):545-9.

77. Hill DR, Beeching NJ. Travelers' diarrhea. Curr Opin Infect Dis. 2010;23(5):481-7.

78. Patel RR, Liang SY, Koolwal P, Kuhlmann FM. Travel advice for the immunocompromised traveler: prophylaxis, vaccination, and other preventive measures. Ther Clin Risk Manag. 2015;11:217-28.

79. DuPont HL, Ericsson CD, Farthing MJ, Gorbach S, Pickering LK, Rombo L, et al. Expert review of the evidence base for prevention of travelers' diarrhea. J Travel Med. 2009;16(3):149-60.

80. Youmans BP, Ajami NJ, Jiang ZD, Campbell F, Wadsworth WD, Petrosino JF, et al. Characterization of the human gut microbiome during travelers' diarrhea. Gut Microbes. 2015;6(2):110-9.

81. McDonald LC. Effects of short- and long-course antibiotics on the lower intestinal microbiome as they relate to traveller's diarrhea. J Travel Med. 2017;24(suppl_1):S35-8.

82. Rasko DA. Changes in microbiome during and after travellers' diarrhea: what we know and what we do not. J Travel Med. 2017;24(suppl_1):S52-S6.

83. Ruiz J, Pons MJ. Prevention of travellers' diarrhoea: where and who? Lancet Infect Dis. 2013;13(11):911-2. 
84. Grundmann H, Klugman KP, Walsh T, Ramon-Pardo P, Sigauque B, Khan W, et al. A framework for global surveillance of antibiotic resistance. Drug Resist Updat. 2011;14(2):79-87.

85. Steffen R, Collard F, Tornieporth N, Campbell-Forrester S, Ashley D,

Thompson S, et al. Epidemiology, etiology, and impact of traveler's diarrhea in Jamaica. JAMA. 1999;281(9):811-7.

86. Thomson MA, Booth IW. Treatment of traveller's diarrhoea. Economic aspects. PharmacoEconomics. 1996;9(5):382-91.

Ready to submit your research? Choose BMC and benefit from:

- fast, convenient online submission

- thorough peer review by experienced researchers in your field

- rapid publication on acceptance

- support for research data, including large and complex data types

- gold Open Access which fosters wider collaboration and increased citations

- maximum visibility for your research: over $100 \mathrm{M}$ website views per year

At $B M C$, research is always in progress.

Learn more biomedcentral.com/submissions 